\title{
1 \\ Towards a Paradigm of Multiparty Negotiation
}

\author{
Larry Crump and A. lan Glendon
}

Source: International Negoatiation, 8(2) (2003): 197-234.

$\mathrm{N}$ egotiations involving multiple parties are complex because of the potential number of interacting variables. Understanding multiparty negotiation is hindered by a lack of theory that can adequately explain the multiplicity of interactions that typically characterize such negotiations. Negotiation sides, parties and roles are just some of the many variables that interact to produce outcomes. The complexity generated through such interaction is a challenge for theory development. This challenge is compounded by misunderstandings about the fundamental nature of multiparty negotiation as an area of study.

Prominent multiparty negotiation studies maintain that the field is neglected (Polzer, Mannix and Neale 1995), having received comparatively little attention from researchers (Kramer 1991), although the present study offers an alternative viewpoint. While the amount of research into multiparty negotiation is considerable, so far no attempt has been made to evaluate the work within a single framework. This article seeks to define multiparty negotiation as a field of study by building a comprehensive framework of multiparty negotiation. A framework is the first step towards a paradigm or model. After building this framework, the article establishes a research agenda for further developing this field of study and practice.

\section{Multiparty Negotiation Concepts and Dynamics}

The concept of "party" was adopted by the negotiation literature from legal studies. In law, a party is the person who files a suit or the person against whom a suit is filed, while that entity's agent is merely a participant (Yarn 1999: 346). In the negotiation literature, party is defined more broadly. A party is a participant in a conflict. Parties can be individuals, groups, organizations, communities or nations (Rubin, Pruitt and Kim 1994: 257). This is an incomplete definition, as a party has functional as well as structural characteristics. Participants in a conflict or in the pursuit of an opportunity (i.e., negotiation) can be parties to a negotiation or parties for a negotiation. At a minimum, a party must be able to (1) make a decision or decisions and (2) communicate such decisions. For example, the components of a disintegrating coalition may each be parties, but the coalition itself may be too conflict-ridden to make or communicate decisions. A disintegrating coalition ceases to be a party at some point in a negotiation. Or, consider a constituent that is not sufficiently organized to make a decision. For example, "the public" is not a party under the proposed definition except when voting in a public referendum. 


\section{Multiparty Negotiation: An Introduction to Theory and Practice}

A clear and concise definition for "party" is critical to the development of a theory on multiparty negotiation. Researchers in this field should engage in debate about how "party" is best conceptualized. This article operationalizes "party" by focusing on an entity's ability to make and communicate decisions.

"Multiparty negotiation" is concerned with more than two parties, including parties or entities on the same side (e.g., primary parties, representatives, agents, advisers, coalitions of parties), on opposing sides (e.g., primary parties, negotiators or disputants), on neutral sides (e.g., all arbitrators and some mediators) and on other sides (e.g., powerful mediators, alternative negotiating partners). "Primary party" is a more precise concept than "negotiator" as the latter concept could be a primary party or an agent for a primary party.

In the present article, a primary party, constituent or its representative is defined as "owning" the problem/opportunity under negotiation and directly experiences the consequences of the negotiated outcome. A representative is distinguished from an agent, as the latter does not own the problem/opportunity under negotiation and is usually retained to serve a primary party or constituent in a negotiation. Agents and primary parties have different motives and interests and can have different goals, standards and ethical norms (Chayes 1999; Fassina 2002; Kramer 1991; Mnookin and Susskind 1999; Rubin and Sander 1988). Primary parties (e.g., constituents) and their agents are analytically distinguishable as separate entities in a negotiation.

A clear and concise definition for "primary party" is critical for developing a comprehensive framework of multiparty negotiation. Researchers in this field should engage in debate about how "primary party" is best conceptualized. This article operationalizes "primary party" by recognizing the utility of "problem-opportunity ownership" and "an entity that directly experiences a negotiated outcome."

Although the concepts of "multiparty" and "multilateral" share a common root there are important distinctions to make. "Multilateral" literally means many-sided (Hampson with Hart 1995: 4), while "bilateral" is two-sided. Multilateral always includes three or more sides. "Biparty," dyadic or two-party negotiation is concerned only with two primary parties. All multilateral negotiations are multiparty, but not all multiparty negotiations are multilateral. Nevertheless, some very complex negotiations are bilateral and multiparty (e.g., consider intellectual property negotiations between the U.S. and China in the 1990s - see Hulse and Sebenius 2003 in this volume of International Negotiation). Distinguishing between multilateral, bilateral, multiparty and biparty negotiations enhances structural clarity.

A number of common "multiparty negotiation situations" can be identified through the literature. This discussion has already distinguished between primary parties and agents, while generally advisers and agents are also clearly distinguishable. For example, a boundary can be established between the process of advising and the process of implementing advice (Salacuse 2000: 7). An adviser transforms into an agent once it communicates (i.e., implements advice) with a second primary party. For example, a two-party or bilateral negotiation can evolve into a multiparty negotiation if an adviser for a primary party becomes directly involved with entities on the other side.

Two other common multiparty negotiation situations include the emergence of a third party (Bercovitch and Jackson 2001; Kramer 1991) or an alternative party 
(alternative negotiating partner). For example, two primary parties and a third party such as a mediator constitute both a bilateral and a multiparty negotiation. The effect of a third party on negotiation process and outcome is well documented (Elkouri and Elkouri 1985; Kressel and Pruitt 1989; Menkel-Meadow 2001; Miller 1994; Wall 1981; Wall, Stark and Standifer 2001). However, the significance of an alternative party to negotiation process and outcome only recently has become more apparent (see Giebels 1999; Giebels, De Dreu and Van de Vliert 1998; Pinkley 1995).

Another common multiparty negotiation situation involves three or more distinct primary parties (Kramer 1991; Polzer, Mannix and Neale 1998; Zartman 1994), while coalition dynamics can structurally transform such multilateral-multiparty negotiations into bilateral negotiations. Distinct parties can and do combine or fuse, but an apparently unitary entity can also fractionate or split (Midgaard and Underdal 1977; Raiffa 1982) into entities of varying degrees of unity. Negotiations would be less complex if parties were monolithic, but often they are not. Monolithic or unitary refers to the internal nature of a party - the degree of internal conflict or cohesion due to similar or different values, interests and/or opinions (Raiffa 1982). A party with a high degree of cohesion is a "unitary party," characterized by consistently coherent behavior and communication with a "single voice."

Any unitary entity, even an individual, can have internal conflict that affects presentation of unity, while a "complex party" - comprising two or more distinct or monolithic parties - can achieve levels of cohesion that result in unitary behavior (Midgaard and Underdal 1977; Raiffa 1982). Such dynamics are structurally significant, as they can determine whether a negotiation is bilateral or multilateral and biparty or multiparty. A multiparty frame of reference may be useful in a negotiation that includes a party that is not generally behaving as a unitary entity.

\section{Multiparty Negotiation Building Blocks and Boundaries}

It is possible to establish the building blocks of multiparty negotiation based on the above discussion. The boundaries of the field can also be defined by identifying such building blocks. "Party" is identified as one of the most basic elements in negotiation, mediation and the entire conflict management literature (Diehl, Druckman and Wall 1998; Wall 1981). Any taxonomy of multiparty negotiation must include "party" as a fundamental concept.

"Relations between parties" has not received as much attention as "party" in the academic literature (Greenhalgh and Chapman 1995). A relationship is a pairing of entities that has meaning to the parties, in which the understood form of present and future interaction influences their behavior today (Sheppard and Tuchinksy 1996: 334). Interestingly, relationships often define roles (Greenhalgh 1995) and parties are normally conceptualized or structured through the use of roles (Zartman 1994). Relations between distinct parties or relations within a complex party are of special significance to multiparty negotiation because the combination or fragmentation of parties is operationalized through a relationship. This article argues that while many important elements can be identified in multiparty negotiation, the two most fundamental elements are (1) party and (2) relations between parties. Combined with the preceding discussion on multiparty negotiation situations, 
this observation provides a foundation for a taxonomy of multiparty negotiation phenomena (see Table 1).

The five phenomena identified in Table 1 are the building blocks of multiparty negotiation. A multiparty negotiation can, but need not, include all five elements.

1. Primary Party Relations - As defined previously, multiparty negotiations will always include three or more primary parties or two primary parties and one other party. That "other party" will have characteristics described by items $2-5$ of Table 1.

2. Cooperative Relations - When there are three or more primary parties some of them may establish cooperative relations. A coalition is the most common cooperative arrangement (a complex entity that is distinct from its component parts), although studies distinguish different coalition types (Boyer and Cremieux 1999; Cobb 1986; Dupont 1996; Holsti, Hopmann and Sullivan 1985; Polzer, Mannix and Neale 1995; Zartman 2003).

3. Non-cooperative Relations - It is not uncommon to find a coalition in disintegration or two entities cooperating on some issues and disputing other issues within the same negotiation. Less common is a single entity, such as a national government, that has sharp internal disagreements that remain unresolved prior to a negotiation with another party (Crump 1995; Midgaard and Underdal 1977; Raiffa 1982). "Single entities" can transform a biparty bilateral negotiation into a multiparty negotiation or even a multilateral negotiation.

4. Third Party Relations - Third parties do not own the problem/opportunity under negotiation but assist primary parties towards an outcome, although this outcome need not be an agreement. Such parties may be unbiased and non-directive but need not be. Third parties can assist (facilitate) primary parties intentionally or unintentionally. They are most often described as mediational and/or arbitrational (Berman and Johnson 1977; Davison 1974; Kressel and Pruitt 1989; Menkel-Meadow 2001; Miller 1994; Sheppard 1984; Susskind 2000; Touval 1975; Touval and Zartman 2001; Wall, Stark and Standifer 2001; Zartman and Touval 1985).

5. Supporting Primary Party Relations - Primary parties may receive assistance from parties that do not "own" the negotiation and are not third parties. Assistance may come indirectly, such as through an alternative negotiating partner, or directly, through advisers and agents (Chayes 1999; Giebels 1999; Mnookin and Susskind 1999; Neale and Bazerman 1991; Pinkley 1995; Salacuse 1995, 2000).

When the multiparty negotiation literature is compared to the list in Table 1 it can be concluded that no other phenomena exist outside of this five-part categorical set.

Table 1: Multiparty negotiation building blocks

(1) Primary party relations (primary parties engaged in a negotiation)

(2) Cooperative relations between parties on the same side (coalitional relations)

(3) Non-cooperative relations inside a "single party" that is not behaving as a unitary entity

(4) Third party relations

(5) Entities providing support to a primary party 
This is not to suggest that other phenomena do not exist - multiparty negotiation represents a large universe of behavior - rather, no other phenomena have been documented in the literature.

These five phenomena represent the building blocks of multiparty negotiation and assist to establish the field's boundaries. However, the "complexity concept" can also be used to determine the boundaries of multiparty negotiation. Complexity is central to multiparty negotiation. For example, "management of complexity" is considered a paradigm for multilateral international negotiations (Zartman 1994; Crump and Zartman 2003). The present study contends that "degrees of complexity" is a central organizing construct for the entire field of negotiation, including biparty, bilateral, multilateral and multiparty negotiations. In establishing multiparty negotiation boundaries this article moves from the least to the most complex form of negotiation.

The line between biparty and multiparty negotiation is ambiguous. It is possible to identify negotiations that are "biparty-plus" and "minimalist-multiparty" in nature. For example, in market-based negotiations, buyers have choices with respect to whom they will engage in biparty, buyer-seller negotiations; sellers who are not selected may serve as alternative negotiating partners for a buyer (Neale and Bazerman 1991). "Alternative parties" can influence biparty negotiation processes even when primary parties have never met these alternative parties (Giebels 1999; Giebels, De Dreu and Van de Vliert 1998; Pinkley 1995). Sometimes, multiparty negotiation analysis cannot explain negotiation process and outcome without taking absent parties into consideration, including alternative parties that primary parties have not encountered. However, to be considered a party in a negotiation, at least one primary party must be aware of this alternative party, and this knowledge must materially influence negotiation behavior.

These phenomena are at the border of multiparty negotiation. The least complex multiparty negotiation involves three negotiating individuals, where two have previously established coalitional relations against the third. A second type of multiparty negotiation with similar complexity would involve two negotiating individuals being assisted by a third, mediating individual. In both examples, complexity is minimized through clearly defined roles.

These examples, representing least-complex multiparty negotiations, serve to establish the inner boundary. Where does the outer boundary lie - what is the most complex multiparty negotiation? There is general agreement in the literature that multilateral negotiations in the international domain present the greatest degree of complexity. For example, the Uruguay GATT (General Agreement on Tariffs and Trade) negotiations formally began in Uruguay in September 1986 with 1,200 official delegates (1,200 negotiators) from over 70 countries (70 primary parties), accompanied by 300 journalists (some journalists likely engaged in facilitative behavior). By December 1990, a GATT meeting in Belgium included over 100 governments, 90 ministers, 1,500 official delegates and as many more advisers, and the same number of journalists. They gathered to finalize a 400 -page agreement that represented the distillation of 1,300 proposals and working papers. However, key parties (the U.S. and the $\mathrm{EU}$ ) found this agreement unacceptable and consequently extended negotiations for three more years. An agreement to establish the World Trade Organization (WTO) was formally concluded by more than 100 governments in Morocco in April 1994 
(Hampson with Hart 1995; Landau 2000; Zartman 1994). The most-complex multiparty negotiation boundary lies somewhere in this location although theoretically there is no "most complex" limit. The GATT example simply identifies the edge of the known universe of empirical cases.

\section{Multiparty Negotiation: Overview and a Research Agenda}

With building blocks identified and boundaries established it is possible to present an overview of the field of multiparty negotiation. This overview will focus on three prominent multiparty negotiation literatures: international negotiations, public disputes, and organizational and group negotiations. A fourth body of literature describing three parties only (triadic interactions) is not considered here. These four distinct literatures represent four multiparty negotiation domains. Disputes or negotiations in the three domains considered here are often embedded in a larger context such that additional parties often become involved as negotiations proceed.

The following discussion introduces the fundamental nature of each multiparty negotiation domain, while considering (1) the academic disciplines involved, (2) each domain's dominant constructs, variables and thematic elements, and (3) critical research questions and areas for future investigation.

\section{International Negotiation}

The international domain of multiparty negotiation draws on many academic disciplines. Political science and international relations established the field, while other disciplines, including international affairs and diplomacy, peace studies, negotiation and conflict management, international environmental policy, international business and management, international organizational studies, international law, social psychology, sociology, history and economics make contributions.

The multiparty international negotiation domain is one of the more developed domains, as research in this field extends into antiquity (Freymond 2002). It includes negotiations within and between international organizations such as governments, NGOs and transnational corporations. Permanent negotiations in international institutions such as the UN or NATO, periodic but regular negotiations in forums (e.g., regional groupings of nations such as APEC) and single but complex and lengthy negotiations, such as multilateral conferences, are prominent within this domain. Less complex phenomena, such as international joint venture negotiations between two corporations or bilateral multiparty negotiations involving governmental entities, are also within this domain (Aurisch 1989; Boyer and Cremieux 1999; Kremenyuk 1991, 2002; Landau 2000; Tinsley and Weiss 1999; Watkins and Rosegrant 2001; Zartman 1994).

An international community comprised of an international institutional order, organizations, regimes, norms, and communities of opinion developed substantially, especially following the Second World War (Druckman 1997; Ruggie 1992). As this international community developed so did the study of international negotiation. (See Kremenyuk (2002) for an appreciation of the richness and diversity of this domain.) Consequently, critical research questions in this domain are numerous - identification of some questions will preclude many others. 
"Multilateral" exists as a concept in all multiparty domains, but the study of multilateral negotiation is most advanced in the international domain (see Hampson with Hart 1995; Zartman 1994; Zartman 2002a; and International Negotiation 8(1) 2003) when compared with other domains. Complexity is a dominant concept in this literature. International negotiation is an exercise in complexity (Winham 1977), which is the prime characteristic of multilateral negotiation (Hampson with Hart 1995). Managing complexity is a dominant construct (Zartman 1994) and a critical area of study. Scholars in this field have extended the utility of "complexity management" to other multiparty negotiation domains. This development holds great potential for enhancing understanding. Of particular interest is identifying concepts and methods to reduce or to manage complexity. Critical research issues in this area include coalition formation and behavior, and the role of leadership in converting structural uncertainty into a form that facilities negotiation outcome (Hampson with Hart 1995; Zartman 2002). These critical research issues are likely to continue, as they are the key tools for managing complexity in international negotiations.

Coalitions or alliances, as a phenomenon and as a conceptual structure, are especially prominent in this literature (Holsti, Hopmann and Sullivan 1985; Walt 1987; Zartman 1994). Coalition building is a metaphor for international negotiation (Dupont 1996) and is the essence of multilateral negotiation (Hampson with Hart 1995). Coalition stability has been a critical area of study for many years, as this variable contributes to an explanation of outcome (Kahan and Rapoport 1984; Pridham 1986). Questions of coalition or alliance stability are prominent in the study of international relations and the international order (see Walt 1987; Waltz 1979) but have received little attention in an international organizational environment where multiple issues in a negotiation can result in a single party engaging in numerous coalitional relations and networks of influence.

Future investigation should seek greater understanding about coalition stability in a multilateral organizational environment where a party cooperates with another party on some issues and competes with that party on other issues. How do parties manage the tension between cooperation and competition and what impact does this have on their effectiveness as coalition partners? How might a negotiation team best manage such circumstances (e.g., individual role assignment, channels of communication, timing, public or private forums)? How does the embedded nature of such relations affect the ability to work together in the present and the future? How does all of this occur when this simple dyadic example operates amidst many other interconnected parties and is really multi-dyadic or multilateral? Answers to such questions will offer insight into the management of complexity at the level of the negotiation team or delegation. This is an especially important level of analysis, as multilateral complexity is often managed through intra-group and inter-group processes.

The relationship between leadership and managing complexity will also be a critical area for continued study. In multilateral international negotiations leadership may be demonstrated through unilateral actions, through coercion and via instrumental techniques based on skill, energy and status (Underdal 1994). We also know that certain specific leadership characteristics are critical for minimizing complexity and facilitating agreement - including innovative thinking, inventiveness, problem solving skill and the ability to broker and make deals (Hampson with Hart 1995), while also acknowledging that attributes such as creativity and problem-solving lie 
beyond quantification (Zartman 2002b). Past research on leadership in international environments has primarily focused on formal and informal leadership in multilateral conferences. While this area of study is essential, knowledge in this area needs to be balanced with insight into the leadership qualities required of each individual conference delegate, as they respond to opportunities and constraints in both international and domestic environments. Putnam (1988) established a theoretical foundation for this field when he outlined the logic of the "two-level games" - or the relationship between domestic politics and international relations. Studies build on this work by considering how a nation's chief executive (e.g., president, prime minister) arrives at an initial strategy towards another state by taking into account the opportunities and constraints imposed by international institutions and his or her own domestic strength taking into account the role of the country's legislative body (Mitchell 2001). Articles in this volume of International Negotiation extend our understanding of the critical nexus between domestic politics and international negotiation (see Kanie 2003; Murphy-Ives 2003). However, the level of analysis for such research is often at a macro level, while research at a micro level is less common.

What we do not clearly understand are the characteristics, skills and abilities that are required of a negotiator to shuttle back and fourth between the international and domestic level - to effectively represent a constituent that may be highly coherent, but may just as likely be lacking a significant degree of unity. It may be that some constituents are so united and focused that they can micro-manage their representative. However, more likely is the scenario that negotiations include representatives with multiple and distinct constituents and/or include a negotiation team that represents various constituencies, as each team member reports back to his or her specific constituency. Coordination between multiple constituents and between each representative on a negotiation team that must itself coordinate with separate constituents is an internal challenge in complexity management.

How are potential issues, parameters, agendas, trade-offs and goals established between a representative and its constituents in such complex settings? What kind of communication occurs between delegate and constituent if adjustments are made initially, throughout the process and as negotiations move toward a conclusion? How is perception of success and/or failure framed - and managed privately and publicly - by the representative and by its constituency initially, as the process unfolds and following the outcome? Some of this activity requires a type of leadership that merits greater theoretical and empirical attention.

Multilateral conferences are a specialized area of study within this domain. Much has been learned over the past 30 years about the preparation, organization and management of international multilateral conferences. Number of parties, type and number of substantive issues, and procedural issues (agenda setting, decision-making rules, etc.) are especially prominent in this sub-domain (Aurisch 1989; Druckman 1997; Hampson with Hart 1995; Midgaard and Underdal 1977). From one perspective a multilateral conference is a massive project that seeks to build some kind of international infrastructure. The field of project management has developed tools and techniques for the effective and efficient construction of large physical infrastructure. Those who conduct and study multilateral conferences could adopt some concepts, processes and methods developed in the study of project management. For example, the concept of modular design could be relevant to the multilateral conference 
organizer (see Watkins 2003 in this volume for an enlightened discussion on the use of modular design in managing war and diplomacy).

Interests, power and security are central themes in this domain. A classic study states: the concept of interest defined as power imposes intellectual discipline upon the observer, infuses rational order into the subject matter of politics, and thus makes the theoretical understanding of politics possible (Morgenthau 1948: 5). Interests and power are assumed to be at the heart of all international negotiations (Leng 1991), while studies present typologies based on these concepts (Martin 1992). This area of study has undergone dramatic transformation in recent years, as the concept of national security has achieved a multidimensional quality. No longer is security synonymous only with the physical well-being of the state; it is now associated with achieving safety from transboundary threats related to the environment, the economy, human rights, and access to food resources, for example (Spector and Wolf 2000: 411). Traditional models of interest, power and security built primarily upon a military-based model will require review given such developments, while greater demands will be placed upon diplomacy (Babbitt 1999; George and Simons 1994; Steiner 2001). Questions for researchers and political leaders might include whether governments can shift their national defense policy machinery towards other issues? If so, how can this shift be achieved? Targeted research is required to find solutions to these and other serious national security challenges.

National security policy has historically revolved around the nation-state as either a source of security (defensive) or a threat to security (offensive). However, the emergence of effective and efficient international terrorist networks (e.g., those responsible for the sabotage of Pan Am Flight 103 out of London in December 1988, the destruction of the World Trade Center in New York in September 2001, the Bali bombings in October 2002) demonstrate that national security theory, policy and practice requires substantial rethinking. For example, what actions can a state legitimately take when a non-state actor, operating in one or more other states, threatens to launch an attack against the people and property of that state. Chapter 7 Article 51 of the UN Charter, which deals with self-defense, was not drafted to respond to such circumstances. Effective self-defense to such a threat is unlikely to include a significant military dimension, while diplomacy, inter-governmental coordination, policing and intelligence provide the greatest long-term potential for effective selfdefense. Unfortunately, these are inefficient tools when compared to the requirement of the challenge. Such observations demonstrate a serious need to reconsider national security policy.

One component of an effective counter-terrorism policy is a sound negotiation theory (Murray 1990). Governments may negotiate with individual terrorists in two types of situations: when they induce an individual terrorist to surrender and when they have a suspected or convicted terrorist under their control (Hayes 2002). However, governmental action may also incite the behavior that negotiations seek to control. Part of an effective negotiation theory should recognize that extreme selfdestructive behavior aimed at violence against people and property could be incited or motivated through revenge for perceived wrongs. Issues of perceived justice and injustice are fundamentally linked to acts of revenge, while conflict escalation is a frequent result of revenge (Kim and Smith 1993). The psychology of these non-state actors, especially their perceived motives and the conceptual structure of 
these motives, requires much greater understanding if a sound negotiation theory is to be established in support of effective counter-terrorism policies.

The problem is further complicated by a Western norm that discourages negotiation with those labeled as villains, as it is believed that negotiation is not a valid conflict-resolution solution when dealing with such parties. To engage a "villain" in negotiation may be perceived as an act of appeasement - as validating the aggression - or as a sign of weakness (Spector 1998). However, communicating with others provides an opportunity to influence their behavior while simultaneously gaining information to identify viable solutions to complex problems. A decision to negotiate with terrorists - when they don't have hostages - requires an essential frame-breaking prenegotiation decision. Implementing such a decision is most effective when an attitude of ethical pragmatism is adopted that seeks to minimize future bloodshed with a business-like approach to conflict resolution (Spector 1998). These broad strokes aimed at terrorism, as an international security issue, only scratch the surface of this very complex problem. Much more research from a negotiation perspective is required, while issues of terrorist motives, justice, injustice, revenge, perceived appeasement, state engagement with non-state actors, and negotiation methods built around attitudes of ethical pragmatism hold considerable potential for a research agenda to these conflict-management challenges.

The use of third parties is almost always a source of support in the management and resolution of complex conflict. A final prominent theme in the international domain that requires consideration is third parties generally, and mediation specifically (Bercovitch and Jackson 2001; Bercovitch and Rubin 1992; Princen 1992; Young 1967). Third parties play a contractual or neutral role in international negotiations or an emergent role where the third party has an interest in the outcome and the power to influence outcomes (Diehl, Druckman and Wall 1998; Lall 1985; Touval 1975; Umbricht 1989; Watkins and Winters 1997; Zartman and Touval 1985). Any actor in the global environment can become a mediator (Bercovitch 1992). An interesting development that should receive greater analytical and theoretical attention considers third-party involvement in coalition building - part of an emerging body of knowledge developing under the concept of "dealcrafting" (Lax and Sebenius 2002). Under what conditions can a mediator effectively assist in building coalitions that are acceptable to the negotiating parties, rather than adopting a less directive or facilitative role? What type of coalitions will produce acceptable and durable outcomes given specific definable characteristics of the conflict and the negotiating parties? What actions are required to move parties toward cooperative or non-cooperative relations with other parties? What sequencing and timing issues serve as intervening variables in such circumstances (Lax and Sebenius 1991). What power sources or resources make such actions possible? What was their effect in producing negotiations (bringing parties to the table) and in producing an outcome? (Zartman 2002a, b).

\section{Public Disputes}

Comparisons are made between public disputes and international negotiation (Susskind and Ozawa 1985). While similarities exist in terms of number of parties, embedded relations and the possible roles that can emerge, an important difference is that public disputes exist at community, state, regional and national levels but not 
at an international level. This domain draws on many academic disciplines. Political science, sociology, social psychology, and economics each make contributions. Professional disciplines also contribute to the public dispute domain, including mediation and facilitation, environmental studies, government, law, management, planning and policy, social work, and urban and regional studies.

Public disputes are distinguished from other types of domestic disputes by the presence of complicated networks of interests and the possibility of new parties emerging as disputes evolve (Carpenter and Kennedy 2001). Two types of public disputes are identified: constitutional disputes and distributional disputes (Susskind and Cruikshank 1987). The former involve legal rights and are the responsibility of the judicial system, while the latter include allocation of public funds, standards setting, facilities siting, or use of public resources such as land, water and energy. Environmental disputes are a prominent part of this multiparty negotiation domain (Amy 1987; Dukes 2001; Ozawa 1993; Susskind 1981; Susskind, Bacow and Wheeler 1983).

Societies without a pluralistic political tradition report conciliatory methods for resolving public disputes ( $\mathrm{Xu}$ 1994). However, the literature in this domain can only be understood in the context of a pluralistic political tradition. Some question the validity of the implicit pluralistic orientation found in public disputes (Modavi 1991), others present dispute resolution methods as an alternative to pluralistic processes (Gray 1989) or note that public disputes emerge primarily because of flaws in representative democracy systems (Susskind and Cruikshank 1987). It is useful to recognize the inherent context of this multiparty domain, as its context contributes to its boundaries and identifies the kind of sociopolitical environment that facilitates its growth and development. Unlike the international domain, the public dispute domain does not exist in every society and nation.

Several themes may be identified in this literature. "Multiparty" has not been adopted to the degree that "multilateral" is used in the international domain. However, the concept is gaining currency in the public dispute domain (Cormick 1989; Gray 1989; Lesnick and Ehrmann 1987; Susskind 2000; Turner and Saunders 1995).

Interests and power (Gray 1989; Susskind and Cruikshank 1987), interests, rights and power (Ury, Brett and Goldberg 1989) and values, trust and power (Carpenter and Kennedy 2001) are significant conceptual structures in the public dispute domain. Interests and power are also identified as important themes in the international domain. Sources of power are widely discussed in the literatures (French and Raven 1959), but are especially prominent through acquisition of process control. Consequently, "dispute procedure management" is a fundamental concern in this domain. Imbeau (1992) considers the relationship between procedures and collective decisions. Carpenter and Kennedy (2001) note that public disputes are a mix of procedures, relationships and substance. Cormick (1989) considers strategic issues in structuring multiparty negotiations in public disputes. Susskind, McKearnan and Thomas-Lamer (1999) and many others focus on consensus-building methods and procedures as an alternative to Robert's Rules of Order.

Generally, leaders control dispute procedures in most organizational and community settings, but leadership is not a prominent topic in this field. The topic is not ignored (Brubaker 1999; Straus 1999b), but it is not often considered either. Rather, coordination (leadership at its most basic) in the form of facilitation, mediation and process consultation is the primary focus of attention in the public 
dispute domain. No other domain in multiparty negotiation is so aligned to a third-party context - a characteristic that may be this domain's greatest strength and greatest weakness - as much of our knowledge about the public dispute process is understood through a third-party context. Arbitration is mentioned in the literature where dispute system design and public disputes intersect (Ury, Brett and Goldberg 1989). Judges and the courts are more prominent in this domain (Golann and Van Loon 1999; Gray 1989). In reality, the courts often represent a BATNA that consensus builders seek to preempt, or at least decrease its attraction. In any event, consensus building through facilitation and mediation is not the only approach for public dispute management; but it is a primary focus in this domain (Allor 1993; Bourdeaux, O'Leary and Thornburgh 2001; Carnevale and Pegnetter 1985; Dukes 1993; Forester and Stilzel 1989; Gray 1989; Poitras and Bowen 2002; Purdy and Gray 1994; Susskind 2000; Susskind and Cruikshank 1987; Susskind, McKearnan and Thomas-Larmer 1999; Susskind and Ozawa 1985).

Although examples of mediators with interests and power can be identified in the literature (Burgess 1983; Hill 1983), this domain is primarily concerned with impartial and contractual mediators or process consultants. During the past 20 years a set of third-party behaviors (a defined role) has evolved to guide the public dispute resolution professional. For example, often a third party conducts a conflict assessment (Susskind and Thomas-Larmer 1999), designs consensus-building strategies and processes - including identification of the stakeholders or parties (Carpenter 1999; Straus 1999a), convenes and manages this process (Carlson 1999; Straus 1999b), assists in producing consensus (McKearnan and Fairman 1999), and assists with consensus implementation (Potapchuk and Crocker 1999). An overall evaluation of this process is best conducted by a trained researcher rather than the third party who facilitated/mediated the process (Innes 1999).

There is no user manual or "cook book" for managing a consensus building process, as such processes are highly dynamic. Nevertheless, over the past 20 years substantial guidance - offered by scholar-practitioners - has developed about the philosophy, strategy, methodology and techniques that can and should be adopted when conducting a consensus-building process (see Carpenter and Kennedy 2001; Dukes, Piscolish and Stephens 2000; Susskind, McKearnan and Thomas-Larmer 1999). However, much is still unknown and many research questions remain. Critical research questions revolve around third-party effectiveness - given the third-party context of the public dispute domain. Scholars have identified eight factors as important to mediation settlement and by extension, mediator effectiveness. First, increasing conflict decreases the potential for settlement. Second, some dispute issues are "toxic" and less likely to facilitate settlement (e.g., disputes involving limited resources). Third, the stage in a conflict when a mediator intervenes is important (intervening either too early or too late contributes to difficulties). Fourth, asymmetrical power between disputants decreases potential for settlement. The literature indicates that these four factors tend to increase the degree of conflict between disputants, serving to restrain mediator effectiveness (Wall, Stark and Standifer 2001). Concurrently, and fifth through eigth, a mediator's ability to bring resources to the table, disputants' commitment to mediation, increased mediator rank and decreased mediator visibility tends to facilitate third-party settlement. Because these latter four factors tend to increase the potential for disputant settlement, they similarly serve to enhance mediator effectiveness (Wall, Stark and Standifer 2001). 
Two observations may be salient based on these conclusions. It is reasonable to assume that other unidentified factors also contribute to increasing or decreasing levels of conflict and increasing or decreasing levels of mediator effectiveness. Identification of these other factors will contribute to managing complexity in the public dispute domain. Second, some of these eight factors are more amenable than others to third-party control, while a well designed research program could assist in identifying how to gain greater control over such factors. Intrinsically, public sector disputes are distributional with too many people and groups wanting too few resources. Unlike the international domain, third parties in the public dispute domain do not often have tangible resources to bring to the table, but they have expertise that can assist in gaining access to resources. For example, developing group problem-solving theory or testing and refining group problem-solving methodology can contribute to minimizing the conflict inherent in public disputes based on a lack of resources. Such theory and techniques can "expand the pie" and identify methods to gain consensus to use resources more efficiently.

Research focused specifically on managing group problem-solving processes in public disputes - large number of stakeholders often with opposing values - could enhance third-party effectiveness. What type of group problem-solving techniques (e.g., traditional public hearings or community forum, task force, joint fact-finding, force field analysis, single-text, visioning, transformative relationship building, policy dialogue, deliberate discourse in a heuristic or algorithmic manner) is most effective at each stage in the consensus-building process (e.g., at start-up, during problem definition, alternative generation, scenario development)? Are different types of group problem-solving techniques more effective with different functional groups (e.g., process-design committees, executive committees, steering committees, comprehensive planning groups)? Are different types of public disputes (e.g., allocation of public funds, standards setting, facilities siting, use of public resources) more effectively managed through different problem-solving techniques (Carpenter 1999; Elliot 1999; Johnson and Johnson 1997; Straus 1999a, b)? These and related questions could enhance third-party effectiveness by developing theory and methodology that is focused specifically on the common problem of scarce resources.

Getting parties to the table is a challenge that has been studied for years in the international domain. What are the factors that trigger parties to actively consider going to the table (e.g., changing conditions and a reassessment, perception of a threat or opportunity, crisis avoidance, the desire to manage a relationship more effectively)? How does an assessment of risks and costs affect motivation to participate? What requirements or expectations do parties have (e.g., reciprocity) and what kind of support is required for participation? (Saunders 1985; Sjostedt 2002; Stein 1989; Zartman 1989). There are significant differences between the international domain and public dispute domain - competitive anarchy often within institutional structures and norms but with ultimate recourse based in power relations vs. representative democracy in a pluralistic society with recourse based in state law. Getting stakeholders to participate is part of a prenegotiation process that has some similarity in function in both domains. Comparative research in this area could provide insights for scholars in each domain if significant differences receive proper analytical treatment.

Third party and coalition phenomena each receive similar attention in the international domain, while the study of coalition phenomena is less prominent in 
the public dispute literature (see Benveniste 1989; Bettencourt 1996; Susskind and Cruikshank 1987). However, consensus building (i.e., a grand coalition) has some similarity to coalition formation and the former is a prominent theme in the public dispute domain (McKinney 1997; Poitras and Bowen 2002; Susskind and Cruikshank 1987; Susskind, McKearnan and Thomas-Lamer 1999). Nevertheless, research that specifically considers coalition dynamics could contribute to a decrease in complexity in this domain. Research questions related to the determinants of coalition formation and coalition stability/instability in public disputes would be a useful place to begin a study. For example, what effect does long-standing positive and negative embedded relations have on coalition formation between stakeholders who are compatible or incompatible on significant issues? How do stakeholders manage inherent complexity when cooperating with parties on some issues and competing with these same parties on other issues? Does third-party behavior intentionally or unintentionally affect coalition formation and stability? Do specific problemsolving methods and the introduction or timing of these methods have an effect on coalition formation - especially in the initial stages of a dispute? Answers to such questions could provide greater understanding of the public dispute process.

\section{Organizational and Group Negotiation}

The range of multiparty negotiation phenomena is broad in the organizational and group domain. For example, international negotiation and public disputes can each be considered in the organizational domain, as most parties engaged in such negotiations are organizations (e.g., cities, states and nations are represented by governments). However, these domains are distinguishable because each has sufficient literature to justify separate consideration. The organizational and group domain draws on many academic disciplines. All of the traditional social sciences contribute to this domain, especially social psychology, management and industrial relations. A number of specialized areas of study are also actively engaged in this field, including organizational behavior, negotiation and conflict management, group dynamics and process, intergroup and intra-group relations, group decision making and task groups.

The organizational domain naturally divides into two types of literature: negotiations between organizations and negotiations inside organizations. The former type includes inter-organizational collaboration and strategic alliance or joint venture negotiations (Chatterjee and Gray 1995; Das and Teng 2002; Fisher 1989; Gilroy 1993; Gray 1985; Inkpen and Ross 2001; Osland and Cavusgil 1998; Pruitt 1994; Schermerhorn 1981; Spekman, Forbes, Isabella and MacAvoy 1998; Watkins 1999; Yoshino and Rangan 1995). A number of themes emerge in the study of negotiations between organizations, while much of this research can be structured through an examination of negotiation process and outcome (Weiss 1997).

Studies of strategic alliance formation identify a range of activities that can be conceptualized through three stages - strategic analysis (e.g., identification of potential for strategy cooperation, cost/benefits of collaborating), partner selection (e.g., goal congruence, internal political support, cultural compatibility) and structuring the relationship (e.g., legal and contractual parameters, contribution of expertise and resources, profit distribution) (Bronder and Pritzl 1992; Spekman, Forbes, Isabella and MacAvoy 1998). The "strategic analysis" stage may focus on seeking solutions to external problems (e.g., protecting existing markets, sharing risk), but a 
review of this literature suggests that substantial attention is devoted to establishing inter-organizational relations to attain some objective or synergy - especially the achievement of competitive advantage (Bronder and Pritzi 1992; Das and Teng 1998; Spekman, Forbes, Isabella and MacAvoy 1998). Given their overarching focus on building a cooperative structure to achieve competitive advantage, strategic alliances generally have a gain-frame orientation. In comparison, public disputes can have either a gain-frame or loss-frame orientation, but resource-deficient disputes - and the accompanying task of dividing scarce resources - indicate a preponderance of loss-frame negotiations. This difference can affect the way parties behave and negotiate. For example, the way a negotiation is framed can affect the way that risk is perceived, which is a contributing factor in determining risk-seeking or risk-avoiding behavior. Gain-framing can contribute to risk-seeking behavior and is more likely to result in agreement. Loss-framing can contribute to resistance in concession making and risk-avoiding behavior and is less likely to result in an agreement (Neale and Bazerman 1991, 1992).

Such dynamics can explain partially why third parties are fundamental to the public dispute process, as the challenges of reaching agreement in this setting require higher degrees of "dispute-resolution technology." Such dynamics can also provide insight into the factors that contribute to strategic alliance failure rates of around 50 percent (Inkpen and Ross 2001), as there may be a relationship between "mutual gain-framing" and the development of agreements that lack durability in complex negotiations.

What are the barriers to settlement when engaged in a complex multiparty interorganizational negotiation that is generally structured as a loss-frame? If agreement is reached, what are the implications for agreement implementation, especially concerning factors such as relational stability and agreement durability? What are the barriers to settlement when engaged in a complex multiparty inter-organizational negotiation that is generally structured in a gain-frame? If agreement is reached, what are the implications for agreement implementation, especially concerning factors such as relational stability and agreement durability? Can insights gained from one, general type of complex multiparty negotiation have relevance for the other type? Integration through specific, theoretical linkage points in the public dispute literature, the inter-organization collaboration literature and the strategic alliance literature can enhance understanding while providing a degree of control over complex inter-organizational multiparty negotiations. In addition, research into cognitive heuristics such as gain/loss-frames are predominately conducted in laboratory settings. Comparative studies of gain-framed and loss-framed inter-organizational negotiations could provide another useful setting for examining and developing such theories (see Bottom 2003 in this volume of International Negotiation for a cutting-edge example of this approach).

Another important theme in the inter-organizational negotiation literature - although highly underdeveloped - is the use of agents, often lawyers in Western societies, who are retained by and report back to principals or constituents (Lax and Sebenius 1986; Mnookin and Susskind 1999; Pruitt 1994; Rubin and Sander 1988). Principals retain agents for their knowledge and skill in getting things done, for the accompanying tactical benefits inherent in the principal-agent relationship (e.g., information management, face-saving techniques), for their emotional detachment 
and for their professional reputation and ability to influence. However, the advantages derived can result in additional financial costs and greater degrees of complexity (e.g., an additional link in the communication process), which can result in potential confusion and misunderstandigs, and principal loss of control over negotiation process (Croson and Mnookin 1997; Fassina 2002; Mnookin 1993; Pruitt 1994; Rubin and Sander 1988; Thompson 2001).

A number of logistical challenges exist when an organization retains an agent. For example, the principal or constituent within the organization will usually have superiors and subordinates who can complicate principal-agent relations and the negotiation process (Thompson 2001). It is not unusual to find chains or networks of principals or constituents and agents (e.g., six or seven separate entities or individuals and groups) spread across an organization, at different levels in the hierarchy, that each have some involvement or an interest in a negotiation with another organization (see Pruitt (1994) for an excellent discussion on this type of structural arrangement). It is also possible that the principal or constituent is not an individual but an organizational committee that lacks unity, or even has committee members who openly compete (Crump 1995). These logistical challenges increase complexity. A research program focused on principal-agent relations in inter-organizational negotiations could identify factors to serve as the basis for prescriptive theory.

Much is known about agents through agency theory, but this body of literature is not readily applied to negotiation (Cutcher-Gershenfeld and Watkins 1999). In negotiations, principals delegate work to agents who are to perform that work. However, in practice astute agents can have substantial control or influence over negotiation process and outcome. Such interaction between principal and agent is known as the mutual influence model, a model considered to have greater validity than the constituent-to-agent influence model (Pruitt 1994). Generally, constituents or principals (i.e., primary parties) and agents have different attitudes toward risk within a specific negotiation. For example, relations between two or more primary parties on the same side and engaged in a coalition are normally structured through risksharing, while principal-agent relations are structured through an exchange - often involving financial compensation. Agent compensation is often based on a fee for service, salary or retainer, while an agent normally has a degree of independence that is greater than the independence common in an employeeemployer supervisory relationship. With this independence comes a concern that agent and principal interests are not always aligned, while agents are most effective when their interests are aligned with those of the principal.

Methods have been devised to "coalign" agent and primary party interests through performance-based contracts or a contingency fee (Eisenhardt 1989; Lax and Sebenius 1986; Rubin and Sander 1988; Thompson 2001; Watkins 1999). Such methods actually shift some outcome risk from the primary party to the agent. Performance-based contracts can transform an agent into another primary party when an agent accepts significant outcome risk, as this type of arrangement results in the agent becoming an outcome owner. The relationship between agent compensation and principal-agent interest co-alignment has received substantial consideration in the literature (see Eisenhardt 1989; Pratt and Zeckhause 1985), although this research does not adequately consider the implications of such dynamics for the study of negotiation. For example, the potential role transformation from agent 
to primary party has implications for the cross-fertilization of knowledge. An agent who accepts significant outcome risk in a negotiation may be better perceived as an entity engaged in a coalition relationship with its constituent, as both are now involved in a risk-sharing arrangement. Might coalition theory have some relevance to such dynamics? Is coalition theory more robust in explaining "agent-principal" relations when the agent has accepted significant outcome risk? Could it be that similar phenomena are the focus of investigation when some scholars study division of coalition gains, while others study agent-principal distribution of gains (agent compensation theory)? Such questions should receive consideration, as there is the potential for knowledge cross-fertilization and theoretical integration. This latter point is especially significant considering the lack of research into principal-agent relations in a negotiation context and the wealth of knowledge on divisions of gains in coalition relations.

The second major area of study in this domain considers negotiations within an organization or intra-organizational negotiation (Bacharach and Lawler 1980; Jameson 1999; Kramer 1991; Lax and Sebenius 1986; Lewicki, Sheppard and Bazerman 1986; Rahim 2001; Walton and McKersie 1965).

Two individuals in dispute within an organization can be considered a biparty negotiation, but the potential intervention of an arbitrating manager or a mediating colleague establishes a multiparty context. Coalitional opportunities, real or imagined, for either individual add another multiparty dimension. The social context of intra-organizational negotiation contributes to its multiparty nature (Kramer 1991; Lewicki, Sheppard and Bazerman 1986; Polzer, Mannix and Neale 1998). Many organizational phenomena involving multiple parties may not be construed as negotiations per se, but negotiation processes may nevertheless play a central role (Kramer 1991: 310).

A number of major themes exist in intra-organizational negotiations. Groups are especially important in this domain. Groups are found both inside and outside of organizations although the academic literature generally places the group within the organization (Davis 1992). Formal groups such as a committee or team, groups within authority structures (e.g., all vice presidents) and coalitions all contribute to intra-organizational decision making and the negotiations that precede decisions (Ancona, Friedman and Kolb 1991; Bazerman, Mannix and Thompson 1988; Brett 1991; Mannix 1993; Polzer, Mannix and Neale 1995, 1998; Rahim 2001; Thibaut and Kelley 1986; Thompson and Fox 2001). Team performance and group effectiveness are important areas of study in this literature. These topics will continue to receive attention in the foreseeable future (DeChurch and Marks 2001; Jehn and Chatman 2000; Kirkman, Jones and Shapiro 2000; Limpman-Blumen and Leavitt 1999).

Organizational coalitions receive special attention in this literature although debate exists over what constitutes a coalition (see Cobb 1986; Sheppard, Lewicki and Minton 1986; Stevenson, Pearce and Porter 1985; Wolf 1986). Two perspectives have emerged. First, organizational coalitions are a strategic and rational response to organizational member concerns where power and resources are pooled to determine decisions. Typically, such coalitions are "issue-focused," exist for short periods and are unstable (Bacharach and Lawler 1980; Cobb 1986; Murnighan and Brass 1991; Stevenson, Pearce and Porter 1985). Second, informal relations are important in the operation of some organizational coalitions. Organization member identity 
and subgroup identification, subgroup member similarity, relationship patterns, and other social psychological processes combine to create informal relations that can become stable "interest-focused" coalitions. Such coalitions have been found to function across issues and situations, and over time (Eisenhardt and Bourgeois 1988; Hogg 1992; Pfeffer 1992; Polzer, Mannix and Neale 1998; Stevenson, Pearce and Porter 1985; Thompson 1967).

Interest-focused coalitions are similar to networks of influence that operate within organizations to control goals and strategic planning, budgets and the allocation of resources, and the appointment of personnel to key positions. The formation of these disperse entities may be less significant than their durability. What are the factors that allow interest-based coalitions to persist in influencing an organization? How do individual members relate to such networks and how do individual members use this entity to gain influence over organizational goals and processes? Do such entities have a life cycle, and if so, what are the factors that result in their disappearance from an organization? Unlike issue-focused coalitions, much is still unknown about the nature of interest-focused coalitions and their ability to mobilize power to control organizational goals and processes. Fortunately, work in this area is emerging in the organizational domain on interest groups and issue-focused groups (Cobb 1986) and on a social-process view of coalitions (Polzer, Mannix and Neale 1998). Research is also beginning to appear in the international domain on policy communities and issue networks (Boyer and Cremieux 1999). Distinguishing between coalition type is a key matter that multiparty theory must clarify in order to enhance understanding of the dynamics created by cooperating primary parties on the same side. For example, degrees of unity determine whether a complex party is unitary or is likely to fragment into two or more competing parties. A highly-unified party can be expected to behave in a significantly different manner than a fragmenting party. Referring to both as a "coalition" establishes the foundation for ambiguous analysis. Research should strive to distinguish between and understand these two classes of phenomena.

Kochan and Bazerman (1986) noted that the coalition literature and the third-party literature are each being integrated into the organizational domain. Historically, industrial relations had a significant impact on the perception of third parties in organizations, as arbitrators and contractual mediators were assumed to be the only third-party types in this domain (Neale and Bazerman 1992). Eventually debate emerged over managers' functional responsibilities, with some arguing that managers were neither mediators nor arbitrators, and others recognizing the mediational and arbitrational processes engaged in by managers (Kochan and Bazerman 1986; Kolb 1986; Kolb and Sheppard 1985; Sheppard 1983). Scholars coined the term "intravenor" to recognize intra-organizational third parties with clout (Carnevale 1986; Conlon 1988; Conlon, Carnevale and Murnighan 1994; Murnighan 1986). A number of other third parties have also been identified in the organizational and group domain. The ombudsman has become a common third-party role in organizations (Gadlin 2000; Kolb 1989; Rowe 1995), while other third parties are mentioned, including consultants (Fisher and Keashly 1988), interveners (Heckscher and Hall 1994) and advocates (Kaufman and Duncan 1989).

The use of formal third parties in intra-organizational settings highlights a corporate desire to manage and control intra-organizational conflict more effectively 
while recognizing that organizational conflict is inevitable. Intra-organizational studies distinguish between substantive conflict and affective conflict and recognize that the former may generally be a functional form of conflict and the latter may be a dysfunctional form of conflict. Studies indicate that too much affective conflict, too little substantive conflict and too much substantive conflict do not contribute to organizational effectiveness. Low levels of affective conflict and moderate levels of substantive conflict can contribute to organizational effectiveness (Masters and Albright 2002; Rahim 2001). The relationship between conflict and organizational effectiveness will continue to receive attention in the academic literature. For example, how can organizational members be taught to effectively manage affective conflict? What type of organizational structures, leadership styles and human resource management policies contribute to moderate levels of substantive conflict? What elements within substantive conflict contribute to organizational effectiveness and how can these elements be enhanced without shifting such conflict into dysfunctionally high or low levels? What is the relationship between intra-organizational conflict resolution systems (i.e., dispute system design), the maintenance of affective conflict at low levels and achievement of substantive conflict at moderate levels? These and many other questions are relevant to the intra-organizational portion of the organizational and group domain.

\section{Theoretical Integration}

Within the multiparty negotiation literature there is recognition of the need for greater theoretical integration (Polzer 1996; Polzer, Mannix and Neale 1998). Also noted is a relationship between advances in the field and increasing degrees of integrative complexity in the field (Kramer 1994). Organizing the multiparty negotiation literature into domains facilitates identification of common phenomena or recurring patterns and provides a basis for engaging in theoretical integration. For example, of the phenomena that are most common, what is the relationship between these phenomena and the theories that can explain them? Answers to these questions will contribute to theoretical integration in the emerging field of multiparty negotiation.

Third-party behavior and coalition behavior were identified in every domain (the latter is often conceptualized as alliance behavior in the international domain and consensus building in the public dispute domain). Yet, the third-party literature and the coalition literature hardly ever intersect (Crump 1997). Only the rare scholar contributes to both fields (e.g., Murnighan 1978, 1986; Raiffa 1982; Wilkinson 1976, while more recent examples include Curran and Sebenius 2003; Watkins 2003 in this volume of International Negotiation). However, coalition and third-party phenomena have the potential to intermingle and integrate. Some of a mediator's leverage derives from the very nature of a three-sided process. Like any triangle, the shape of a mediated negotiation contains the potential for a coalition to be formed (Touval 1994: 51). Specifically, three parties may interact when dealing with a common issue, and a possibility exists that two parties may form a coalition against the other or that one party may mediate between the other two parties. Mediational and coalitional behavior can occur in a single period of interaction in a negotiation (Belliveau and Stolte 1977; Kriesberg 1991; Touval 1975; Van de Vliert 1981; Wilkinson 1976). While the present study is not the first to recognize a 
relationship between third-party behavior/theory and coalition behavior/theory, it is the first to recognize the significance of this link as a point of integration for the field of multiparty negotiation. After reviewing the multiparty negotiation literature by domains it may be concluded that third-party theory and coalition theory are two of the major theories in this field of study. This specific point of integration could contribute to the development of a comprehensive multiparty negotiation model - a development that would further contribute to the establishment of a paradigm of multiparty negotiation.

Integration of coalitional and mediational theory/behavior may not be so common in some domains (e.g., settings that depend on formal contractual mediators) and therefore may be less relevant for some negotiation and mediation practitioners. Concurrently, other settings tolerate and even accept third parties with alignments to a primary party. We first became aware of such phenomena through the international domain (Touval 1975; Touval and Zartman 1989; Zartman and Touval 1985) followed by the organizational domain (Carnevale 1986; Conlon 1988; Conlon, Carnevale and Murnighan 1994; Murnighan 1986). In addition, third parties that are aligned to one or more primary parties are common in cultures that are highly formal (on a formal - informal scale) and that also seek to avoid conflict. Such cultures (e.g., Japan) are dependent on the use of introductions for making initial contact with others. Should problems emerge several years later, the "introducer" will often feel obligated to act as a "go-between" or informal mediator. In cross-cultural negotiations, for example, it is not unusual for one party to loose contact with its future mediator (often a Western party), while the other party (often the Japanese) maintain and nurture this important business relationship. Relational or alignment dynamics between this "go-between" and the primary parties could be one factor in explaining settlement (Crump 1998; Gestland 1999), although this is another area that requires greater empirical attention.

At a theoretical level the relationship between coalition behavior/theory and third-party behavior/theory could provide a foundation for a comprehensive model of multiparty negotiation.

\section{Conclusion}

Some studies argue that researchers have neglected multiparty negotiation (Kramer 1991; Polzer, Mannix and Neale 1995), while the present article offers an alternative point of view by presenting a comprehensive perspective of multiparty negotiation. This study builds on the work of many negotiation scholars to provide an understanding or a context for conceptualizing multiparty negotiation phenomena - a multiparty negotiation framework. This framework, which has five components and is organized from macro to micro, is summarized in Table 2.

The discussion focused initially on the fundamentals of multiparty negotiation concepts and dynamics, then on the establishment of multiparty building blocks and

Table 2: A multiparty negotiation framework

(1) Multiparty negotiation boundaries

(2) Multiparty negotiation domains

(3) Taxonomy of multiparty negotiation building blocks

(4) Integration of the two major multiparty negotiation theories

(5) Fundamental multiparty negotiation concepts and dynamics 
boundaries, and the identification of a significant point of theoretical integration. A review of multiparty negotiation domains combined to produce a multiparty negotiation framework. This article also sought to provide guidance by building a multiparty negotiation research agenda through a review of critical knowledge in each domain.

There are many wise men and women around these days, each of whom is an expert regarding some particular anatomical part of the great elephant. What we sorely need are more people with expertise in the contours of the beast as a whole (Rubin 1983: 216). The purpose of the present study is to outline the contours of that "beast" known as multiparty negotiation, while defining and describing this emerging field of study. In this regard, "sides" and "parties" serve as a dual lense that allows for the structuring of complex negotiation phenomena. Such tools assist in answering the basic analytical question: how are negotiation outcomes achieved and explained (see Young 1991; Zartman 1988).

Many researchers seek to identify and understand the vast array of elements that are conceptualized as negotiation, while progress must also be made in integrating these elements into some form of comprehensive understanding. Unfortunately, insufficient work has been devoted to this latter task in the field of multiparty negotiation. Such work is especially critical as this field of study advances through increasing degrees of integrative complexity. The framework presented in this study serves as a foundation for building a paradigm of multiparty negotiation. How should such developments proceed? Scholars devoted to advancing the field of multiparty negotiation should strive to build structural models that establish order within the complexity. Descriptive models that identify the nature of critical theoretical relationships are required, as this is an important step in developing a multiparty negotiation paradigm and advancing the development of multiparty negotiation theory and practice. Predictive and prescriptive theory, built on causal relationships, depends upon well-grounded descriptive theory or structural models (Pruitt 1995). The aim of the present article is to begin the process of responding to this important gap in the literature.

In this regard, the proposed framework holds the potential to assist in developing a comprehensive model of multiparty negotiation. For example, five multiparty negotiation building blocks were identified utilizing "party" and "relations between parties" as conceptual constructs - (1) primary party relations, (2) cooperative relations between parties on the same side, (3) non-cooperative relations inside a "single party" that is not behaving as a unitary entity, (4) third-party relations and (5) relations that provide support to a primary party. The present article argues that all parties within defined multiparty negotiation boundaries will have the fundamental characteristics of one of these five types. No other phenomenon has been or will be observable in any domain in any negotiation, past, present or future. This is a large claim.

Variations within each party type exist. For example, there are clear differences between a third party with and without power, a third party with and without outcome interests and a third party with and without a bias (partiality) toward one or more primary parties. All these examples depict an entity playing the functional role of a third party. However, it is also important to acknowledge that a "third party with power and outcome interests" can transform into a "primary party" (e.g., a helpful mediating neighbor suddenly becomes your competitor) as negotiations proceed, as there is a similarity between a third party with power and outcome 
interests, and a primary party engaged in some form of mediational behavior. Role transition does not weaken the validity of this five-part taxonomy of building blocks unless an entity is able to transform into a type that is fundamentally distinct from parties described by this taxonomy.

Role theory is especially useful for distinguishing between variations within a party type. For example, differences between the functional role of an agent and that of an adviser are apparent, as advisers become agents when first communicating with a second primary party. Unfortunately, distinctions between other roles are more subtle. For example, a negotiator can simultaneously play a bargaining and representative role (Druckman 1978), although a functional role (in this case outcome ownership) and not a behavioral role distinguishes a negotiating primary party from its agent. Role theory is an operational tool that can support the development of multiparty negotiation theory. Can a theoretical structure be created that defines the range of possible roles within each party type? This challenge and opportunity confronts scholars studying complex negotiation processes. It may be possible to build a structural model or paradigm of this universe known as multiparty negotiation based on role theory by establishing logical links between elements within the taxonomy of multiparty negotiation building blocks. Once constructed, this model's validity can be established by looking at a range of case studies in various domains to determine whether parties that do not fit within this model exist. A taxonomy of multiparty negotiation roles, constructed from the building blocks of multiparty negotiation, can contribute to the development of predictive and prescriptive theory, as a greater understanding of negotiation-role behavior should contribute to greater control in studying determinants or variables that have predictive qualities.

The present article offers a framework for understanding multiparty negotiation, while establishing a foundation for a multiparty negotiation paradigm. This framework, like the study of multiparty negotiation, is in a developmental state. For example, the organizational domain may give birth to other domains as sufficient literature builds to justify independent consideration. The present framework has specific limitations, as it is not the definitive work on multiparty negotiation; rather, it is a proposed structure that seeks to reflect current developments.

No study has previously sought to map the field of multiparty negotiation or establish a framework for this field of study. The purpose of mapping is to replace ambiguity and disorder with clarity. Ultimately, a map offers guidance. This framework should provide greater understanding of multiparty negotiation process and outcome, and facilitate an integration of knowledge that may contribute to advances in theoretical development.

\section{References}

Allor, D.J. (1993) “Alternative forums for citizen participation: Formal mediation of urban land use disputes," The International fournal of Conflict Management 4(2): 167-180.

Amy, D.J. (1987) The Politics of Environmental Mediation. New York, NY: Columbia University Press.

Ancona, D.G., Friedman, R.A. and Kolb D.M. (1991). "The group and what happens on the way to Yes," Negotiation Fournal 7(2): 155-173.

Aurisch, K.L. (1989) “The art of preparing a multilateral conference," Negotiation fournal 5(3): $279-288$.

Babbitt, E.F. (1999) "Challenges for international diplomatic agents," in R.H. Mnookin and L.E. Susskind, editors, Negotiating on Behalf of Others. Thousand Oaks, CA: Sage, pp. 135-150. 
Bacharach, S.B. and Lawler, E.J. (1980) Power and Politics in Organizations. San Francisco, CA: Jossey-Bass.

Bazerman, M.H., Mannix, E.A. and Thompson, L.L. (1988) "Groups as mixed-motive negotiations," in E.J. Lawler and B. Markovsky, editors, Advances in Group Processes. Greenwich, CT: JAI, pp. 195-216.

Belliveau, L.M. and Stolte, J.F. (1977) "The structure of third party intervention," The Fournal of Social Psychology 103 (December): 243-250.

Benveniste, G. (1989) Mastering the Politics of Planning. San Francisco, CA: Jossey-Bass.

Bercovitch, J. (1992) "Mediators and mediation strategies in international relations," Negotiation fournal 8(2): 99-112.

Bercovitch, J. and Jackson, R. (2001) "Negotiation or mediation?: An exploration of factors affecting the choice of conflict management in international conflict," Negotiation fournal 17(1): 59-77.

Bercovitch, J. and Rubin, J.Z. (1992) Mediation in International Relations: Multiple Approaches to Conflict Management. London: Macmillan.

Berman, M.R. and Johnson, J.E. (1977) Unofficial Diplomats, New York, NY: Columbia University Press.

Bettencourt, B.A. (1996) "Grassroots organizations: Recurrent themes and research approaches," Fournal of Social Issues 52(1): 207-220.

Bottom, W.P. (2003) "Keynes'attack on the Versailles Treaty: An early investigation of the consequences of bonded rationality, framing, and cognitive illusion," International Negotiation 8(2): 367-402.

Bourdeaux, C., O'Leary, R. and Thornburgh, R. (2001) "Control communication, and power: A study of the use of alternative dispute resolution of enforcement actions at the U.S. Environmental Protection Agency," Negotiation fournal 17(2): 175-191.

Boyer, B. and Cremieux, L. (1999) "The anatomy of association: NGO's and the evolution of Swiss climate and biodiversity policies," International Negotiation 4(2): 255-282.

Brett, J.M. (1991) "Negotiating group decisions," Negotiation fournal 7(3): 291-310.

Bronder, C. and Pritzl, R. (1992) "Developing strategic alliances: A conceptual framework for successful co-operation," European Management fournal 10(4): 412-421.

Brubaker, D. (1999) "Organizational trauma recovery," in L. Susskind, S. McKearnan and J. Thomas-Larmer, editors, The Consensus Building Handbook. Thousand Oaks, CA: Sage, pp. 1051-1064.

Burgess, H. (1983) "Environmental mediation," in L. Susskind, L. Bacow and M. Wheeler, editors, Resolving Environmental Regulatory Disputes. Cambridge, MA: Schenkman, pp. 156-221.

Carlson, C. (1999) "Convening," in L. Susskind, S. McKearnan and J. Thomas-Larmer, editors, The Consensus Building Handbook. Thousand Oaks, CA: Sage, pp. 169-197.

Carnevale, P.J. (1986) "An unnecessary neologism in two systems of mediation," Negotiation fournal 2(4): 357-361.

Carnevale, P.J. and Pegnetter, R. (1985) "The selection of mediation tactics in public sector disputes: A contingency analysis," Journal of Social Issues 41(2): 65-81.

Carpenter, S. (1999) "Choosing appropriate consensus building techniques and strategies," in L. Susskind, S. McKearnan and J. Thomas-Larmer, editors, The Consensus Building Handbook. Thousand Oaks, CA: Sage, pp. 61-97.

Carpenter, S.L. and Kennedy, W.J.D. (2001) Managing Public Disputes. San Francisco, CA Jossey-Bass.

Chatterjee, K. and Gray, B. (1995) "International joint ventures: Economic and organizational perspectives," Group Decision and Negotiation 4(5): 379-382.

Chayes, A.J. (1999) "Preface," in R.H. Mnookin and L.E. Susskind, editors, Negotiating on Bebalf of Others. Thousand Oaks, CA: Sage, pp. ix-xi.

Cobb, A.T. (1986) "Coalition identification in organizational research," in R.J. Lewicki, B.H. Sheppard and M.H. Bazerman, editors, Research on Negotiation in Organizations. Greenwich, CT: JAI, pp. 139-154.

Conlon, D.E. (1988) "The mediation-intravention discussion: Toward an integrative perspective," Negotiation fournal 4(2): 143-148.

Conlon, D.E., Carnevale, P.J. and Murnighan, J.K. (1994) "Intravention: Third-party intervention with clout," Organizational Behavior and Human Decision Processes 57: 387-410. 
Cormick, G.W. (1989) "Strategic issues in structuring multi-party public policy negotiations," Negotiation fournal 5(2): 125-132.

Croson, R. and Mnookin, R.H. (1997) "Does disputing through agents enhance cooperation? Experimental evidence," Fournal of Legal Studies 26(2): 331-345.

Crump, L. (1995) Koshojutsu: Nintendo Dai-league wo Kau (English title - Negotiation Skill: How Nintendo Purchased a Major League Baseball Team). Tokyo: Bungeishunju, Ltd.

Crump, L. (1997) "Integrating coalition theory and third party theory: Toward a comprehensive model of multiparty negotiation," in N. Harrison, editor, Decision Sciences Institute: Conference Proceedings. Sydney, AU: Woodslane Pitman, pp. 154-157.

Crump, L. (1998) Nihonjin no tameno Harvardryu Koshojutsu (English title - Integrative Strategy and Japanese Style Negotiation: A Comparative Analysis). Tokyo: Nihon Noritsu Kyokai.

Crump, L. and Zartman, I.W. (2003) "Multilateral Negotiation and the Management of Complexity," International Negotiation 8(1): 1-5.

Curran, D. and Sebenius, J. (2003) "George Mitchell in Northern Ireland: Enabling a coalition of the center," International Negotiation 8(1): 111-147.

Cutcher-Gershenfeld, J. and Watkins, M. (1999) "Toward a theory of representation in negotiation," in R.H. Mnookin and L.E. Susskind, editors, Negotiating on Behalf of Others. Thousand Oaks, CA: Sage, pp. 23-51.

Das, T.K. and Teng, B.S. (2002) "Alliance constellations: A social exchange perspective," Academy of Management Review 27(3): 445-456.

Davis, J.H. (1992) "Introduction to the special issue on group decision making," Organizational Behavior and Human Decision Processes 52(1): 1-2.

Davison, W.P. (1974) Mass Communication and Conflict Resolution: The Role of the Information Media in the Advancement of International Understanding. New York, NY: Praeger.

DeChurch, L.A. and Marks, M.A. (2001) "Maximizing the benefits of task conflict: The role of conflict management," The International Journal of Conflict Management 12(1): 4-22.

Diehl, P.H., Druckman, D. and Wall, J. (1998) "International peacekeeping and conflict resolution: A taxonomic analysis with implication," Fournal of Conflict Resolution 42(1): 33-55.

Druckman, D. (1978) "Boundary role conflict: Negotiation as a dual responsiveness," in I.W.Zartman, editor, The Negotiation Process: Theories and Applications. Beverly Hills, CA: Sage, pp. 87-110.

Druckman, D. (1997) "Dimensions of international negotiation: Structures, processes, and outcome," Group Decision and Negotiation 6(5): 395-420.

Dukes, F. (1993) "Public conflict resolution: A transformative approach," Negotiation fournal 9(1): 45-57.

Dukes, F.E. (2001) "Integration of environmental conflict," Conflict Resolution Quarterly 19(1): $103-115$

Dukes, E.F., Piscolish, M.A. and Stephens, J.B. (2000) Reaching for Higher Ground in Conflict Resolution. San Francisco, CA: Jossey-Bass.

Dupont, C. (1996) "Negotiation as coalition building," International Negotiation 1(1): 47-64.

Eisenhardt, K.M. (1989) "Agency theory: An assessment and review," Academy of Management Review 14(1): 57-74.

Eisenhardt, K. and Bourgeois, L. (1988) "Politics of strategic decision making in high-velocity environments: Toward a midrange theory," Academy of Management fournal 31(4): 737-770.

Elkouri, F. and Elkouri, E. (1985) How Arbitration Works, 4th ed. Washington, DC: BNA Books.

Fassina, N.F. (2002) "Direct and representative negotiation: A principal-agent authority continuum," Prepared for International Association for Conflict Management 15th Annual Conference. Park City, Utah.

Fisher, R. (1989) "Negotiating inside out: What are the best ways to relate internal negotiations with external ones?," Negotiation fournal 5(1): 33-41.

Fisher, R.J. and Keashly, L. (1988) "Third party interventions in intergroup conflict: Consultation is not mediation," Negotiation fournal 4(4): 381-393.

Forester, J. and Stilzel, D. (1989) "Beyond neutrality: The possibilities of activist mediation in public sector conflict," Negotiation fournal 5(3): 251-264.

French, J.R.P. Jr. and Raven, B.H. (1959) “The bases of social power”, in D. Cartwright, editor, Studies in Social Power. Ann Arbor, MI: University of Michigan Press, pp. 150-167. 
Freymond, J.F. (2002) "Historical approaches", in V.A. Kremenyuk, editor, International Negotiation: Analysis, Approaches Issues, 2nd ed. San Francisco, CA: Jossey-Bass, pp. 131-144.

Gadlin, H. (2000) "The ombudsman: What's in a name," Negotiation fournal 16(1): 37-48.

George, A.L. and Simons, W.E. (1994) The Limits of Coercive Diplomacy, 2nd ed. Boulder, CO: Westview Press.

Gestland, R.R. (1999) Cross-cultural Business Behavior. Copenhagen, Denmark: Copenhagen Business School.

Giebels, E. (1999) What If this is as Good as it Gets: Alternative Partners and Social Motives of Negotiators. Veenendaal, The Netherlands: Universal Press.

Giebels, E., De Dreu, C.K.W. and Van de Vliert, E. (1998) "The alternative negotiator as the invisible third at the table," The International Fournal of Conflict Management 9(1): 5-21.

Gilroy, B.M. (1993) Networking in Multinational Enterprises: The Importance of Strategic Alliances. Columbia, SC: University of South Carolina Press.

Golann, D. and Van Loon, E.E. (1999) "Legal issues in consensus building", in L. Susskind, S. McKearnan and J. Thomas-Larmer, editors, The Consensus Building Handbook. Thousand Oaks, CA: Sage, pp. 495-525.

Gray, B. (1985) “Conditions facilitating interorganizational collaboration," Human Relations 38(10): 911-936.

Gray, B. (1989) Collaborating: Finding Common Ground for Multiparty Problems. San Francisco, CA: Jossey-Bass.

Greenhalgh, L. (1995) "Competition in a collaborative context: Toward a new paradigm," in R.J. Bies, R.J. Lewicki and B.H. Sheppard, editors, Research on Negotiation in Organizations. Greenwich, CT: JAI, pp. 251-270.

Greenhalgh, L. and Chapman, D.I. (1995) "Joint decision making: The inseparability of relationships and negotiation," in R.M. Kramer and D.M. Messick, editors, Negotiation as a Social Process. Thousand Oaks, CA: Sage, pp. 166-185.

Hampson, F.O. with Hart, M. (1995) Multilateral Negotiations: Lessons from Arms Control, Trade, and the Environment. Baltimore, MD: The Johns Hopkins University Press.

Hayes, R.E. (2002) "Negotiations with terrorists," in V.A. Kremenyuk, editor, International Negotiation: Analysis, Approaches Issues, 2nd ed. San Francisco, CA: Jossey-Bass, pp. 416-429.

Heckscher, C. and Hall, L. (1994) "Mutual gains and beyond: Two levels of intervention," Negotiation fournal 10(3): 235-248.

Hill, S. (1983) "Intergovernmental grant negotiation (The Jackson Case)," in L. Susskind, L. Bacow and M. Wheeler, editors, Resolving Environmental Regulatory Disputes. Cambridge, MA: Schenkman, pp. 156-221.

Hogg, M.A. (1992) The Social Psychology of Group Cobesiveness: From Attraction to Social Identity, New York, NY: New York University Press.

Holsti, O.R., Hopmann, P.T. and Sullivan, J.D. (1985) Unity and Disintegration in International Alliances. Lanham, MD: University Press of America.

Hulse, R. and Sebenius, J. (2003) "Sequencing, acoustic separation, and 3-D negotiation of complex barriers: Charlene Barshefsky and I.P. rights in China," International Negotiation 8(2): 311-338.

Imbeau, L.M. (1992) "Procedural constraints and conflictual preferences in collective decisionmaking," The International fournal of Conflict Management 3(3): 181-206.

Inkpen, A.C. and Ross, J. (2001) "Why do some strategic alliances persist beyond their useful life?," California Management Review 44(1): 132-148.

Innes, J.E. (1999) "Evaluating consensus building”, in L. Susskind, S. McKearnan and J. ThomasLarmer, editors, The Consensus Building Handbook. Thousand Oaks, CA: Sage, pp. 631-675.

Jameson, J.K. (1999) "Toward a comprehensive model for the assessment and management of intraorganizational conflict: Developing the framework," The International fournal of Conflict Management 10(3): 268-294.

Jehn, K.A. and Chatman, J.A. (2000) "The influence of proportional and perceptual conflict composition on team performance," The International fournal of Conflict Management 11(1): 56-73.

Johnson, D.W. and Johnson, F.P. (1997) Foining Together: Group Theory and Group Skills. Boston, MA: Allyn and Bacon. 
Kahan, J.P. and Rapoport, A. (1984) Theories of Coalition Formation. London: Lawrence Erlbaum.

Kanie, N. (2003) "Leadership in multilateral negotiation and domestic policy: The case of the Netherlands' Kyoto protocol negotiations," International Negotiation 8(2): 339-365.

Kaufman, S. and Duncan, G.T. (1989) "Third party intervention: A theoretical framework," in M.A. Rahim, editor, Managing Conflict: An Interdisciplinary Approach. New York, NY: Praeger, pp. 273-289.

Kim, S.H. and Smith R.H. (1993) "Revenge and conflict esclation," Negotiation fournal 9(1): 37-43.

Kirkman, B.L., Jones, R.G. and Shapiro, D.L. (2000) "Why do employees resist teams? Examining the 'resistance barrier' to work team effectiveness," The International fournal of Conflict Management 11(1): 74-92.

Kochan, T.A. and Bazerman, M.H. (1986) "Macro determinants of the future of the study of negotiations in organizations," in R.J. Lewicki, B.H. Sheppard and M.H. Bazerman, editors, Research on Negotiation in Organizations. Greenwich, CT: JAI, pp. 287-309.

Kolb, D.M. (1986) "Who are organizational third parties and what do they do?," in R.J. Lewicki, B.H. Sheppard and M.H. Bazerman, editors, Research on Negotiation in Organizations. Greenwich, CT: JAI, pp. 207-228.

Kolb, D.M. (1989) "Labor mediators, managers, and ombudsmen: Roles mediators play in different contexts," in K. Kressel and D.G. Pruitt, editors, Mediation Research: The Process and Effectiveness of Third-party Intervention. San Francisco, CA: Jossey-Bass, pp. 91-114.

Kolb, D.M. and Sheppard, B.H. (1985) "Do managers mediate, or even arbitrate?," Negotiation fournal 1(4): 379-388.

Kramer, R.M.(1991) "The more the merrier? Social psychological aspects of multiparty negotiations in organizations," in M.H. Bazerman, R.J. Lewicki and B.H. Sheppard, editors, Handbook on Negotiation in Organizations. Greenwich, CT: JAI Press, pp. 307-332.

Kramer, R.M. (1994) "Integrative complexity and conflict theory: Evidence of an emerging paradigm," Negotiation fournal 10(4): 347-357.

Kremenyuk, V.A., editor (1991) International Negotiation: Analysis, Approaches, Issues, San Francisco, CA: Jossey-Bass.

Kremenyuk, V.A., editor (2002) International Negotiation: Analysis, Approaches, Issues, 2nd ed. San Francisco, CA: Jossey-Bass.

Kressel, K. and Pruitt, D.G., editors (1989) Mediation Research: The Process and Effectiveness of Thirdparty Intervention. San Francisco, CA: Jossey-Bass.

Kriesberg, L. (1991) "Formal and quasi-mediators in international disputes: An exploratory analysis," Fournal of Peace Research 28(1): 19-27.

Lall, A.S. (1985) Multilateral Negotiation and Mediation. New York, NY: Pergamon.

Landau, A. (2000) "Analyzing international economic negotiations: Towards a synthesis of approaches," International Negotiation 5(1): 1-19.

Lax, D.A. and Sebenius, J.K. (1986) The Manager as Negotiator: Bargaining for Cooperation and Competitive Gain. New York, NY: The Free Press.

Lax, D.A. and Sebenius, J.K. (1991) "Thinking coalitionally: Party arithmetic, process opportunism, and strategic sequencing," in H.P. Young, editor, Negotiation Analysis. Ann Arbor, MI: University of Michigan Press, pp. 153-193.

Lax, D.A. and Sebenius, J.K. (2002) "Dealcrafting: The substance of three-dimensional negotiations," Negotiation fournal 18(1): 5-28.

Leng, R. (1991) "International conflict negotiation: Contributions from political science," in M.H. Bazerman, R.J. Lewicki and B.H. Sheppard, editors, Handbook on Negotiation in Organizations. Greenwich, CT: JAI Press, pp. 119-137.

Lesnick, M.T. and Ehrmann, J.R. (1987) "Selecting strategies for managing multiparty disputes," Mediation Quarterly 16(1): 31-44.

Lewicki, R.J., Sheppard, B.H. and Bazerman, M.H., editors (1986) Research on Negotiation in Organizations. Greenwich, CT: JAI.

Limpman-Blumen, J. and Leavitt, H.J. (1999) Hot Groups: Seeding Them, Feeding Them and Using Them to Ignite Your Organization. New York: Oxford University Press.

Mannix, E.A. (1993) "Organizations as resource dilemmas: The effects of power balance on coalition formation in small groups," Organizational Behavior and Human Decision Processes 55(1): 1-22. 
Martin, L.L. (1992) "Interests, power, and multilateralism," International Organization 46(4): $565-792$.

Masters, M.F. and Albright, R.R. (2002) The Complete Guide to Conflict Resolution in the Workplace. New York, NY: American Management Association.

McKearnan, S. and Fairman D. (1999) "Producing consensus," in L. Susskind, S. McKearnan and J. Thomas-Larmer, editors, The Consensus Building Handbook. Thousand Oaks, CA: Sage, pp. 325-373.

McKinney, M. (1997) “The challenge of funding consensus-building processes," Negotiation fournal 13(3): 235-241.

Menkel-Meadow, C. (2001) Mediation: Theory, Policy and Practice. Aldershot, UK: Ashgate Dartmouth.

Midgaard, K. and Underdal, A. (1977) "Multiparty conferences," in D. Druckman, editor, Negotiations: Social-psychological Perspectives. Beverly Hills, CA: Sage, pp. 329-345.

Miller, F. (1994) Arbitration. Kent UK: Ruthtrek.

Mitchell, D. (2001) "International institutions and Janus faces: The influence of international institutions on central negotiators within two-level games," International Negotiation 6(1): 25-48.

Mnookin, R.H. (1993) "Why negotiations fail: An exploration of barriers to the resolution of conflict," The Obio State fournal of Dispute Resolution 8(2): 235-249.

Mnookin, R.H. and Susskind, L.E., editors (1999) Negotiating on Bebalf of Others. Thousand Oaks, CA: Sage.

Modavi, N. (1991) "The political economy of environmental conflicts: An analytical framework," The International Fournal of Conflict Management 2(1): 27-44.

Morgenthau, H.J. (1948) Politics Among Nations: The Struggle for Power and Peace. New York, NY: Alfred A. Knopf.

Murnighan, J.K. (1978) "Models of coalition behavior: Game theoretic, social psychological, and political perspectives," Psychological Bulletin 85(5): 1130-1153.

Murnighan, J.K. (1986) "The structure of mediation and intravention," Negotiation fournal 2(4): 351-356.

Murnighan, J.K. and Brass, D.J. (1991) "Intraorganizational coalitions," in M.H. Bazerman, R.J. Lewicki and B.H. Sheppard, editors, Handbook on Negotiation in Organizations. Greenwich, CT: JAI, pp. 283-306.

Murphy Ives, P. (2003) "Global trade in telecommunications negotiations: The role of progressive multilateralism," International Negotiation 8(1): 43-78.

Murray, J.S. (1990) "Negotiating U.S. policy to counter terrorism," Negotiation fournal 6(1): 15-22.

Neale, M.A. and Bazerman, M.H. (1991) Cognition and Rationality in Negotiation. New York, NY: Free Press.

Neale, M.A. and Bazerman, M.H. (1992) "Negotiator cognition and rationality: A behavioral decision theory perspective," Organizational Behavior and Human Decision Processes 51(2): 157-175.

Osland, G.T. and Cavusgil, T. (1998) "The use of multiple-party perspectives in international joint venture research," Management International Review 38(3): 191-202.

Ozawa, C. (1993) "Improving citizen participation in environmental decision-making - the use of transformative mediator techniques," Environment and Planning 11: 103-117.

Pfeffer, J. (1992) Managing with Power: Politics and Influence in Organizations. Boston, MA: Harvard Business School Press.

Pinkley, R.L. (1995) "Impact of knowledge regarding alternatives to settlement in dyadic negotiations," Fournal of Applied Psychology 80(3): 403-417.

Poitras, J. and Bowen, R.E. (2002) "A framework for understanding consensus-building initiation," Negotiation fournal 18(3): 211-232.

Polzer, J.T. (1996) "Intergroup negotiation: The effects on negotiating teams," Fournal of Conflict Resolution 40(4): 678-698.

Polzer, J.T., Mannix, E.A. and Neale, M.A. (1995) "Multiparty negotiation in its social context," in R.M. Kramer and D.M. Messick, editors, Negotiation as a Social Process. Thousand Oaks, CA: Sage, pp. 123-142. 
Polzer, J.T., Mannix, E.A. and Neale, M.A. (1998). "Interest alignment and coalitions in multiparty negotiation," Academy of Management Fournal 41(1): 42-54.

Potapchuk, W.R. and Crocker, J. (1999) "Implementing consensus-based agreements," in L. Susskind, S. McKearnan and J. Thomas-Larmer, editors, The Consensus Building Handbook. Thousand Oaks, CA: Sage, pp. 527-555.

Pratt, J.W. and Zeckhauser, R.J. (1985) Principals and Agents: The Structure of Business. Boston, MA: Harvard Business School Press.

Pridham, G. (1986) Coalition Behavior in Theory and Practice: An Inductive Model for Western Europe. Cambridge, UK: Cambridge University Press.

Princen, T. (1992) Intermediaries in International Conflict. Princeton, NJ: Princeton University.

Pruitt, D.G. (1994) "Negotiation between organizations: A branching chain model," Negotiation fournal 10(3): 217-230.

Pruitt, D.G. (1995) "Networks and collective scripts: Paying attention to structure in bargaining theory," in R.M. Kramer and D.M. Messick, editors, Negotiation as a Social Process. Thousand Oaks, CA: Sage, pp. 37-47.

Purdy, J.M. and Gray, B. (1994) "Government agencies as mediators in public policy conflicts," The International Fournal of Conflict Management 5(2): 158-180.

Putnam, R.D. (1988) “Diplomacy and domestic politics: The logic of two-level games," International Organization 42(3): 427-460.

Rahim, M.A. (2001) Managing Conflict in Organizations, 3rd ed. Westport, CT: Quorum Books.

Raiffa, H. (1982) The Art and Science of Negotiation, Cambridge, MA: The Belknap Press of Harvard University.

Rowe, M.P. (1995) "Options, functions, and skills: What an organizational ombudsperson might want to know," Negotiation fournal 11(2): 103-114.

Rubin, J.Z. (1983) "The use of third parties in organizations: A critical response," in M.H. Bazerman and R.J. Lewicki, editors, Negotiating in Organizations. Beverly Hills, CA: Sage, pp. 214-224.

Rubin, J.Z., Pruitt, D.G. and Kim, S.H. (1994) Social Conflict: Escalation, Stalemate and Settlement, 2nd ed. New York, NY: McGraw-Hill.

Rubin, J.Z. and Sander, F.E.A. (1988) "When should we use agents?: Direct vs. representative negotiation," Negotiation fournal 4(4): 395-401.

Ruggie, J.G. (1992) "Multilateralism: The anatomy of an institution," International Organization 46(3): 561-598.

Salacuse, J.W. (1995) "The art of advising negotiators," Negotiation fournal 11(4): 391-401.

Salacuse, J.W. (2000) The Wise Adviser: What every Professional should Know about Consulting and Counseling. Westport, CT: Praeger.

Saunders, H.H. (1985) "We need a larger theory of negotiation: The importance of prenegotiation phases," Negotiation fournal 1(3): 249-262.

Schermerhorn Jr., J.R. (1981) "Open questions limiting the practice of interorganizational development," Group \& Organization Studies 6(1): 83-95.

Sheppard, B.H. (1983) "Managers as inquisitors: Some lessons from the law," in M.H. Bazerman and R.J. Lewicki, editors, Negotiating in Organizations. Beverly Hills, CA: Sage, pp. 193-213.

Sheppard, B.H. (1984) "Third party conflict intervention: A procedural framework," in B.M. Staw and L.L. Cummings, editors, Research in Organizational Behavior: Greenwich, CT: JAI, pp. 141-190.

Sheppard, B.H., Lewicki, R.J. and Minton, J.W. (1986) "A new view of organizations: Some retrospective comments,” in R.J. Lewicki, B.H. Sheppard and M.H. Bazerman, editors, Research on Negotiation in Organizations. Greenwich, CT: JAI, pp. 311-321.

Sheppard, B.H. and Tuchinksy, M. (1996) "Interfirm relationships: A grammar of pairs," in B. Staw and L.L. Cummings editors, Research in Organizational Behavior: Greenwich, CT: JAI, pp. 331-373.

Sjostedt, G. (2002) "Negotiation on trade and the environment: Variation in the multilateral approach," in V.A. Kremenyuk, editor, International Negotiation: Analysis, Approaches Issues, 2nd ed. San Francisco, CA: Jossey-Bass, pp. 362-374.

Spector, B.I. (1998) "Deciding to negotiate with villains," Negotiation fournal 14(1): 43-59.

Spector, B.I. and Wolf, A. (2000) "Negotiating security: New goals, changed process," International Negotiation 5(3): 411-426. 
Spekman, R.E., Forbes III, T.M., Isabella, L.A. and MacAvoy, T.C. (1998) "Alliance management: A view from the past and a look to the future," Fournal of Management Studies 35(6): 747-772.

Steiner, B.H. (2001) "Diplomacy as independent and dependent variable," International Negotiation 6(1): 79-104.

Stevenson, W.B., Pearce, J.L. and Porter, L.W. (1985) "The concept of 'coalition' in organization theory and research," Academy of Management Review 10(2): 256-268.

Straus, D.A. (1999a) "Designing a consensus building process using a graphic road map," in L. Susskind, S. McKearnan and J. Thomas-Larmer, editors, The Consensus Building Handbook. Thousand Oaks, CA: Sage, pp. 137-168.

Straus, D.A. (1999b) "Managing meetings to build consensus," in L. Susskind, S. McKearnan and J. Thomas-Larmer, editors, The Consensus Building Handbook. Thousand Oaks, CA: Sage, pp. 287-323.

Stein, J.G. (1989) Getting to the Table: The Process of International Prenegotiation. Baltimore, MD: The Johns Hopkins University Press.

Susskind, L. (1981) "Environmental mediation and the accountability problem," Vermont Law Review 6(1): 1-47.

Susskind, L. (2000) “Confessions of a public dispute mediator,” Negotiation fournal 16(2): 129-132.

Susskind, L., Bacow, L. and Wheeler, M. (1983) Resolving Environmental Regulatory Disputes. Cambridge, MA: Schenkman Books.

Susskind, L. and Cruikshank, J. (1987) Breaking the Impasse: Consensual Approaches to Resolving Public Disputes. New York, NY: Basic Books.

Susskind, L., McKearnan, S. and Thomas-Larmer, J., editors (1999) The Consensus Building Handbook: A Comprehensive Guide to Reaching Agreement. Thousand Oaks, CA: Sage.

Susskind, L. and Ozawa C. (1985) "Mediating public disputes: Obstacles and possibilities," Fournal of Social Issues 41(2): 145-159.

Susskind, L. and Thomas-Larmer, J. (1999) "Conducting a conflict assessment," in L. Susskind, S. McKearnan and J. Thomas-Larmer, editors, The Consensus Building Handbook Thousand Oaks, CA: Sage, pp. 99-136.

Thibaut, J.W. and Kelley, H.H. (1986) The Social Psychology of Groups, revised ed. London: Transaction Publishers.

Thompson, J.D. (1967) Organizations in Action. New York, NY: McGraw-Hill.

Thompson, L.L. (2001) The Mind and Heart of the Negotiator, 2nd ed. Upper Saddle River, NJ: Prentice Hall.

Thompson, L.L. and Fox, C.R. (2001) "Negotiation within and between groups in organizations: Levels of analysis," in M.E. Turner, editor, Groups at Work: Theory and Research. Mahwah, NJ: Lawrence Erlbaum, pp. 221-266.

Tinsley, C.H. and Weiss, S.E. (1999) "Examining international business negotiations and directions for the future," International Negotiation 4(1): 95-97.

Touval, S. (1975) "Biased intermediaries: Theoretical and historical considerations," The ferusalem Fournal of International Relations 1(1): 51-69.

Touval, S. (1994) "Why the U.N. fails," Foreign Affairs 73(5): 44-57.

Touval, S. and Zartman I.W. (1989) "Mediation in international conflict," in K. Kressel and D.G. Pruitt, editors, Mediation Research: The Process and Effectiveness of Third-Party Intervention. San Francisco, CA: Jossey-Bass, pp. 115-137.

Touval, S. and Zartman, I.W. (2001) "International mediation in the post-cold war era," in C.A. Crocker, F.O. Hampson, and P. Aall, editors, Managing Global Chaos, 2nd ed. Washington, DC: U.S. Institute of Peace.

Turner, B. and Saunders, R. (1995) "Mediating a planning scheme amendment: A case study in the co-mediation of a multiparty planning dispute," Australian Dispute Resolution Fournal 6(4): 284-296.

Umbricht, V.H. (1989) Multilateral Mediation: Practical Experiences and Lessons. Boston, MA: Martinus Nijhoff.

Underdal, A. (1994) "Leadership theory: Rediscovering the arts of management," in I.W. Zartman, editor, International Multilateral Negotiation: Approaches to the Management of Complexity. San Francisco, CA: Jossey-Bass. 
Ury, W.L., Brett, J.M. and Goldberg, S.B. (1989) Getting Disputes Resolved: Designing Systems to Cut the Cost of Conflict. San Francisco, CA: Jossey-Bass.

Van de Vliert, E. (1981) "Siding and other reactions to a conflict: A theory of escalation toward outsiders," Fournal of Conflict Resolution 25(3): 495-520.

Wall, J.A., Jr. (1981) "Mediation: An analysis, review, and proposed research," Fournal of Conflict Resolution 25(1): 157-180.

Wall, J.A., Jr., Stark, J.B. and Standifer, R.L. (2001) "Mediation: A current review and theory development," Fournal of Conflict Resolution 45(3): 370-391.

Walt, S.M. (1987) The Origins of Alliances. Ithaca, NY: Cornell University Press.

Walton, R.E. and McKersie, R.B. (1965) A Behavioral Theory of Labor Negotiations: An Analysis of a Social Interaction System. New York, NY: McGraw-Hill.

Waltz, K.N. (1979) Theory of International Politics. New York, NY: Random House.

Watkins, M. (1999) "Negotiating in a complex world," Negotiation fournal 15(3): 245-270.

Watkins, M. (2003) "Strategic simplification: Toward a theory of modular design in negotiation," International Negotiation 8(1): 149-167.

Watkins, M. and Rosegrant, S. (2001) Breakthrough International Negotiation: How Great Negotiators Transformed the World's Toughest post-war Conflicts. San Francisco, CA: Jossey-Bass.

Watkins, M. and Winters, K. (1997) "Intervenors with interests and power," Negotiation fournal 13(2): 119-142.

Weiss, S.E. (1997) "Explaining outcomes of negotiation: Toward a grounded model for negotiations between organizations," in R.L. Lewicki, R.J. Bies and B.H. Sheppard, editors, Research on Negotiation in Organizations. Greenwich, CT: JAI, pp. 247-333.

Wilkinson, D. (1976) Cohesion and Conflict: Lessons From the Study of Three-party Interaction. London: Frances Pinter.

Winham, G.R. (1977) "Complexity in international negotiation," in D. Druckman, editor, Negotiations: Social-psychological Perspectives. Beverly Hills, CA: Sage, pp. 347-366.

Wolf, G. (1986) "The concept of coalition in organizations," in R.J. Lewicki, B.H. Sheppard and M.H. Bazerman, editors, Research on Negotiation in Organizations. Greenwich, CT: JAI, pp. $175-178$.

Xu, X. (1994) "People's conciliation: A mode of conflict management of civil disputes in China," The International Fournal of Conflict Management 5(4): 326-342.

Yarn, D.H. (1999) Dictionary of Conflict Resolution. San Francisco, CA: Jossey-Bass.

Yoshino, M.Y. and Rangan, U.S. (1995) Strategic Alliances: An Entrepreneurial Approach to Globalization. Boston, MA: Harvard Business School Press.

Young, H.P. (1991) Negotiation Analysis. Ann Arbor, MI: The University of Michigan.

Young, O.R. (1967) The Intermediaries: Third Parties in International Crisis. Princeton, NJ: Princeton University Press.

Zartman, I.W. (1988) "Common elements in the analysis of the negotiation process," Negotiation Fournal 4(1): 31-43.

Zartman, I.W. (1989) "Prenegotiation: Phases and functions," in J.G. Stein, editor, Getting to the Table: The Process of International Prenegotiation. Baltimore, MD: The Johns Hopkins University Press, pp. 1-17.

Zartman, I.W. editor (1994) International Multilateral Negotiation: Approaches to the Management of Complexity. San Francisco, CA: Jossey-Bass.

Zartman, I.W. (2002a) "The structure of negotiation," in V.A. Kremenyuk, editor, International Negotiation: Analysis, Approaches Issues, 2nd ed. San Francisco, CA: Jossey-Bass, pp. 71-84.

Zartman, I.W. (2002b) "What I want to know about negotiations," International Negotiation 7(1): $5-15$.

Zartman, I.W. (2003) "Conclusion: Managing complexity," International Negotiation 8(1): 179-186.

Zartman, I.W. and Touval, S. (1985) "International mediation: Conflict resolution and power politics," Fournal of Social Issues 41(2): 27-45. 